\title{
STAPHYLOCOCCAL CYSTITIS IN A GYNAECOLOGICAL WARD
}

\author{
BY \\ DONALD J. H. PAYNE \\ From the Public Health Laboratory, Northallerton
}

(RECEIVED FOR PUBLICATION JULY 5, 1958)

Cross-infection of wounds in hospital is well recognized. Similar infection of the urinary tract received less attention until Ørskov $(1952,1954)$ showed that many urinary infections in certain Copenhagen hospitals were due to the same organism. She was able to identify the Klebsiella strains by their biochemical and antigenic properties. Kirby, Corpron, and Tanner (1956) mention instances in which cross-infection by antibiotic-resistant staphylococci outside the urinary tract was proved by phage-typing, but point out that there is no simple way of labelling coliform organisms so as to identify cross-infecting strains of the urinary tract. They described infections of the urinary tract with coliform organisms which were resistant to antibiotics. When such organisms were encountered in patients without previous antibiotic therapy, the cases were regarded as being due to cross-infection. The methods of sterilization of the catheters and irrigation solutions were satisfactory, and they suggested, therefore, that the organisms originated in the naso-pharynx of the hospital staff or from heavily contaminated blankets.

Dutton and Ralston (1957), dealing with urinary tract infection in a male urological ward, found evidence of cross-infection. Winchester bottles for collecting urine from patients with indwelling catheters, urinals, nurses' hand towels, nurses' hands, ward air, and dust were found to carry organisms similar to those infecting the urinary tracts of the patients.

This report deals with an outbreak of Staphylococcus aureus cystitis in a gynaecological ward. Phage-typing showed that the organisms were probably all derived from a common source.

\section{Cases of Cystitis}

In August, 1955, it was noticed by Dr. P. N. Coleman that the frequency with which he isolated Staphylococcus aureus from the urine of patients in the ward was increasing.
The histories of all patients admitted to the ward from the middle of May to the end of October were therefore examined. Thirty-seven of $138 \mathrm{had}$ cystitis. In each case the disease was characterized by frequent dysuria and pyrexia. The bacteriological results are given in Table I, from which

TABLE I

INCIDENCE AND TYPE OF CYSTITIS

\begin{tabular}{c|c|c|c|c}
\hline $\begin{array}{c}\text { Total } \\
\text { No. of } \\
\text { Patients }\end{array}$ & $\begin{array}{c}\text { Staph. aureus } \\
\text { Phage } \\
\text { Type 7 }\end{array}$ & $\begin{array}{c}\text { Staph. aureus } \\
\text { Not } \\
\text { Typed }\end{array}$ & Bact. coli & Sterile \\
\hline 138 & 12 & 8 & 14 & 3 \\
\hline
\end{tabular}

it will be seen that 20 of the infections were due to Staphylococcus aureus. All 20 strains were resistant to penicillin and streptomycin, very sensitive to chlortetracycline, and slightly sensitive to chloramphenicol. Twelve of the 20 strains were phage-typed by Dr. E. H. Gillespie of the Public Health Laboratory, Sheffield, and all 12 were phage-type 7.

Eighteen of the 20 patients infected with Staphylococcus aureus had previously passed sterile urine. Of the two patients who had not, one had previously yielded Staphylococcus aureus (not phage-typed) and is not included as a case of cross-infection. From the other patient, $P s$. pyocyanea was isolated from an earlier urine.

\section{Search for Source of Infection}

Surgeons.-As all the infections occurred after operations, the question arose whether they were associated with one particular surgeon. The fact that surgeon $A$ had nine cases and surgeon $B$ had 10 proved that this was not so. Neither surgeon carried the epidemic strain in his nose. The relation was then considered of the incidence of cystitis to the type of surgical operation used (Tables II and III). It was evident that the incidence of cystitis was greater after vaginal than after abdominal operations. 
TABLE II

INCIDENCE OF STAPHYLOCOCCUS AUREUS CYSTITIS RELATED TO NATURE OF OPERATION

\begin{tabular}{c|c|c|c|c}
\hline $\begin{array}{c}\text { No. of } \\
\text { Cases }\end{array}$ & $\begin{array}{c}\text { Vaginal } \\
\text { Repairs }\end{array}$ & $\begin{array}{c}\text { Vaginal } \\
\text { Hysterectomies } \\
\text { under } \\
\text { Anaesthesia } \\
\text { and } \\
\text { Dilatation and } \\
\text { Currettage }\end{array}$ & $\begin{array}{c}\text { Abdominal } \\
\text { Operations }\end{array}$ \\
\hline 19 & 9 & 1 & 5 \\
\hline
\end{tabular}

TABLE III

TYPE OF OPERATION AND INCIDENCE OF INFECTION

\begin{tabular}{ll|c|c|c}
\hline & & $\begin{array}{c}\text { Staphylococcus } \\
\text { aureus }\end{array}$ & $\begin{array}{c}\text { Coliform } \\
\text { Organisms }\end{array}$ & $\begin{array}{c}\text { No } \\
\text { Infection }\end{array}$ \\
\hline $\begin{array}{l}\text { Vaginal operations } \\
\text { Abdominal }, "\end{array}$ & $\ldots$ & 14 & 11 & 7 \\
\hline
\end{tabular}

It therefore appeared that infection was introduced either in the theatre or in the ward during the postoperative routine. The surgeons themselves carried out catheterization in the theatre; as the surgeons were shown to be free from Staphylococcus aureus type 7, it was concluded that infection was introduced in the ward. The finding of the epidemic strain in two specimens of urine without any pus suggested that the organism was introduced during catheterization. The pre-operative and post-operative ward routines were next investigated.

Pre-operation Routine.-In May, the month before the increase of cases of cystitis, all patients of surgeon B undergoing vaginal operations had a penicillinstreptomycin pessary inserted in the vagina for three nights before operation. This became routine for both surgeons in mid-September. The pessaries were inserted by a nurse whose hand was protected with a boiled, dried, and powdered but non-sterile glove. The gloves were hung to dry on a line in the sterilizing room adjacent to the ward, from the dust of which the epidemic strain was isolated. Six special blankets for use on the theatre trolley were kept for these patients; they were removed in the anaesthetic room and never taken into the theatre.

Catheterization Routine.-Catheters were passed by the staff nurse or a senior nurse who had been adequately instructed. Technique was conventional except that gloves were not worn. The catheter lubricant consisted of tragacanth jelly with phenyl mercuric nitrate. In May, 1955, a change was made ; this mixture was steamed for half an hour, then 150 $\mathrm{mg}$. of dihydrostreptomycin was added to $120 \mathrm{~g}$. of the original mixture.

After operation, patients either had an indwelling catheter for 48 hours and/or were catheterized eighthourly until the residual urine was less than $2 \mathrm{oz}$.

Nasal Carriers. - Nasal swabs were taken from the doctors, nurses, and ward cleaners. Three nurses harboured the epidemic strain, staff nurse $M$ who performed most of the catheterizations and two nurses who worked for a period of only one week in the infected ward. Five infections occurred during the absence of nurse $M$. It was therefore assumed that she was a recipient and not the reservoir of the epidemic strain.

Blankets and dust were sampled and Staphylococcus aureus of the epidemic type was isolated from two out of four blankets, four out of five samples of ward dust, and from dust in the sterilizing room.

\section{Preventive Measures}

The ward and side rooms were washed with soap and water from floor to ceiling and then re-decorated. Blankets were treated with "lissapol" and "cirrasol OD" (Blowers and Wallace, 1955).

The catheterization routine was modified so that masks and gowns were worn, and hands were scrubbed for at least three minutes and dried on a sterile towel before sterile gloves were put on. Great care was taken with the preparation of the patient ; "dettol" was being used to swab the vulva. No catheter lubricant was used. The name of the nurse performing the catheterization was recorded each time. Penicillin-streptomycin pessaries ceased to be used.

\section{Results}

During the next 17 months only one case of staphylococcal cystitis occurred after 384 similar operations.

\section{Discussion}

The pattern of the sensitivity of the organism to antibiotics was the same for all the organisms that were typed, namely, resistant to penicillin and streptomycin, very sensitive to chlortetracycline, and slightly sensitive to chloramphenicol. This supports the belief that we were dealing with a single strain of Staphylococcus aureus. How it was introduced it is impossible to say, as investigations were not begun until four months after the first diagnosis of staphylococcal cystitis. By this time the organism was generally distributed in the dust and blankets, although it was isolated from only a few members of the nursing staff.

The possibility that the staphylococcus was in the catheter lubricant must be considered. Although no tests were made, the method of preparation and sterilization makes this most unlikely. It may have come from the hands of the nurses catheterizing the patients, but there was no obvious relation between the nurses carrying the epidemic strain and the patients infected.

The original suggestion made by Kirby et al. (1956) that infection in such cases is due to contamination of sterile catheters by organisms from the blankets and dust at the time of catheterization must be considered the most likely 
explanation. It is hardly surprising that the trouble arose after the introduction of penicillinstreptomycin pessaries, because any substance that removes the normal bacterial flora leaves the treated area ripe for colonization by antibioticresistant organisms, including staphylococci.

\section{Summary}

An account is given of staphylococcal cystitis due to cross-infection. It is suggested that the infection was due to catheterization and was favoured by the use of antibiotic pessaries. The organisms probably came from the blankets and dust. Measures taken to reduce this source of infection were successful in controlling the outbreak.

I wish to thank Mr. J. S. Hovell and Mr. K. Girgis for their help and co-operation which made this investigation possible, and Miss Yarker, the ward sister, for her valuable assistance.

\section{REFERENCES}

Blowers, R., and Wallace, K. R. (1955). Lancet, 1, 1250.

Dutton, A. A. C., and Ralston, M. (1957). Ibid., 1, 115.

Kirby, W. M. M., Corpron, D. O., and Tanner, D. C. (1956). J. Amer. med. Ass., 162, 1.

Ørskov, I. (1952). Acta path. microbiol. scand., Suppl. 93, p. 259. (1954). Ibid., 35, 194.

\section{Correction}

In the paper "Compleximetric Determination of Calcium in Pathological and Physiological Specimens," by D. N. Baron and Joyce L. Bell (J. clin. Path., 1959, 12, 143), there is an error in the last paragraph of column 2 on page 143 . The second sentence should read:

"Then $1 \mathrm{ml}$. urine is added to the first tube and $0.2 \mathrm{ml}$. to the second tube." 